\title{
Breast Milk Production in terms of Knowledge of Postpartum Mother about the Initiation of Early Breastfeeding in Newborns
}

\author{
Siti Patonah, Dwi Agung Susanti, Dara Dwifa Anggraita \\ Akademi Kesehatan Rajekwesi, Bojonegoro, East Java, Indonesia \\ Corresponding author: sitipatonah73@gmail.com
}

\begin{abstract}
Background: Many mothers do not know about the benefits of Breast Crawl. Often mothers have an improper understanding, such as not having to breastfeed the baby because the breast milk has not come out or because the milk that comes out first and yellow is the dirt and stale. Purpose: This study aimed to know the relationship of postpartum knowledge about Breast Crawl in newborn with the smoothness of milk production.

Method: This research use analytical method with cross sectional approach. The study was conducted on May 29 to June 23, 2018. The population in this study were all post partum mothers in Sri Widayati Wiwik BPS, SST Tanggungan Ngraho Sub-district Bojonegoro Regency in 2018 as many as 22 people, the sample size of 22 postpartum women was taken by purposive sampling technique. The instrument used is a questionnaire, then performed data processing through editing, coding, scoring and tabulating and analysis of data with Cross tables.

Results: The results showed that 22 postpartum mothers in BPS Wiwik Sri Widayati, SST Tanggungan Ngraho Sub-district Bojonegoro Regency is knowledgeable good of 11 people, more than half the smoothness of breast milk production smoothly for 14 people $(63,64 \%)$.

Conclusion: There is relation of maternal knowledge about Breast Crawl on newborn with smoothness of breast milk production at BPS Wiwik Sri Widayati, SST Tanggungan Ngraho Sub-district Bojonegoro Regency. From the results of this study should postpartum mother can improve knowledge especially about Breast Crawl in newborn by coming to counseling conducted by health workers at Maternal \& Child Health Centre every month.
\end{abstract}

Keywords: Knowledge, Postpartum Mother, Breast Crawl, Breastmilk Production

How to Cite: Patonah, S., Susanti, D.A., \& Anggraita, D.D. (2019). Breast Milk Production in terms of Knowledge of Postpartum Mother about the Initiation of Early Breastfeeding in Newborns. Journal Of Nursing Practice, 3(1), 114-122. https://doi.org/10.30994/jnp.v3i1.73 


\section{BACKGROUND}

WHO through Unicef recommends breastfeeding your baby immediately within 1 hour after birth. When the first hour after the baby is born, the baby's instinct takes him to look for his mother's nipples, the behavior is known as the Early Breastfeeding Initiation (IMD) (Baskoro A, 2008: 29). There are so many benefits for babies and mothers by giving breast milk immediately after giving birth, psychologically and physiologically. For babies, coming into contact with the mother's skin provides warmth, calmness, and breathing, and a regular heartbeat. Babies get colostrum that is rich in antibodies which can mean the baby gets the first immunization. For mothers, touch and suck on the breast encourages the formation of oxytocin. Oxytocin stimulates other hormones that cause the mother to feel safe and comfortable, and of course encourages the smooth flow of breast milk (Rosita S, 2008: 108109). Mother's knowledge about IMD is very important. Many mothers do not know about the benefits of IMD. Often mothers have an incorrect understanding, for example they do not need to feed the baby because breast milk has not yet come out or because the milk that comes out first and is yellow is dirt and stale. Other things that make breastfeeding delayed are for example the mother feels thirsty and needs to rest first because she is tired, still feeling sick, or thinks the baby needs to be bathed first (Anjasmara J, 2015). Phenomenon in BPS Wiwik Sri Widayati, SST Dependent Ngraho Subdistrict, Bojonegoro Regency, many mothers do not understand the initiation of early breastfeeding because of the lack of information obtained by health workers, there are still many puerperal mothers having elementary or junior high school education and many of them have not initiated early breastfeeding at their baby.

Unicef data states that IMD within 1 hour after the baby is born can reduce the death rate by 22 percent or almost a quarter of the number of babies born before 1 month of age in developing countries (Armadhi H, 2015: 1). Data from the World Health Organization (WHO) in 2016 still shows that the average number of exclusive breastfeeding in the new world is around 38 percent. When compared with the WHO target of $50 \%$, the number is still far from the target. Based on data collected by the 2014 International Baby Food Action Network (IBFAN), Indonesia ranks lowest in the 51 countries in the world that have taken part in assessing the status of policies and programs for infant and young children (Pramita E, 2017) . Nutrition Status Monitoring (PSG) results in 2016, the percentage of newborns who received Early Breastfeeding Initiation (IMD) in 2016 was $51.9 \%$ consisting of $42.7 \%$ getting Early Breastfeeding Initiation (IMD) within $<1$ hour after birth and $9.2 \%$ in an hour or more. The highest percentage was in DKI Jakarta Province (73\%) and the lowest was Bengkulu $(16 \%)$ while in East Java the number of newborns received an Early Breastfeeding Initiation (IMD) <1 hour by $50.7 \%$ and $>1$ hour by $12.0 \%$ ( RI Ministry of Health, 2017: 138). From the data of the Bojonegoro District Health Office the number of babies given exclusive breastfeeding in 2016 reached $88.2 \%$, this achievement is lower when compared to 2015 which reached $89.4 \%$. In the Ngraho Community Health Center, out of 319 infants aged 0-6 months who were exclusively breastfed, were 301 (94.4\%) (Health Profile of the Bojonegoro District Health Office 2016). Based on BPS data Wiwik Sri Widayati, SST Tanggungan Ngraho District Bojonegoro Regency the number of postpartum mothers in 2017 was 47 people. From the initial survey conducted on 3 postpartum mothers on 30 December 2017 it was found that all postpartum mothers did not know about the initiation of early breastfeeding and $100 \%$ did not initiate early breastfeeding.

Early Breastfeeding Initiation or the beginning of early breastfeeding is the baby starts breastfeeding himself after birth. Contact between the baby and her mother's skin is left for at least one hour immediately after birth, then the baby will look for the mother's breast by itself. The way the baby initiates breastfeeding is called the brest crawl or crawl looking for breasts (Sondakh JS, 2013: 170). According to the Ministry of Health of the Republic of Indonesia (2010: 30), there are several factors that influence the successful implementation of Early Breastfeeding Initiation, including policies on health service institutions regarding exclusive breastfeeding and breastfeeding, knowledge, motivation and attitudes of birth attendants, 
knowledge, motivation and attitudes of mothers, support from family members . The success of a mother's early breastfeeding is influenced by one of them is knowledge, high maternal knowledge has a positive influence on breastfeeding for her baby. More knowledge will influence someone to make better decisions (MOH RI, 2010: 27). The benefits of initiating early breastfeeding include stimulating the release of the breastfeeding hormone, when skin contact occurs between the mother and baby the release of the hormone oxytocin. The hormone oxytocin is a hormone that is responsible for the expenditure of milk. and other benefits of IMD, which are reducing the risk of infant death. Ayi who suckles in the first hour will be better able to survive during the first month of her life. The longer the delay the greater the risk of death (Irsal FS, 2017: 38).

In order for this early initiation to work, full support from various parties is needed. Both government policies, health workers, family members, and the general public need to create conditions that can encourage mothers to breastfeed their babies immediately within the first hour of life (Rosita S, 2008: 109). Mothers should breastfeed their children as often as possible because breast milk thus increases and is sufficient for the baby's needs. The mother should breastfeed her children until the second year of the child's life and if possible for a long time. Support from the family, especially the husband is needed by the mother who will do the IMD after giving birth. Some actions that can be done especially by the husband are giving attention to the wife such as stroking her hair and with words that can be soothing (Baskoro A, 2008: 28). It is recommended for health workers to deliver IMD information to parents and family before doing IMD. It is also recommended to create an atmosphere that is calm, comfortable and full of patience to give the baby a chance to crawl in search of the mother's breast or "the breast crawl" (Roesli U, 2008: 4). The role of midwives in the success of exclusive IMD and ASI cannot be separated from the authority of midwives in providing services to mothers and children as stipulated in Kepmenkes no 900 / Menkes / SK / 2002 Chapter V Article 18 namely increasing the maintenance and use of breast milk. And the government's effort through the Minister of Health has issued a circular about strengthening the implementation of the Ten Steps to Successful Breastfeeding (10 LMKM) to all provincial and district / city health offices and government and private hospitals throughout Indonesia. The purpose of strengthening these $10 \mathrm{LMKMs}$ is that all health service facilities have a commitment to establish written policies that support increased breastfeeding by carrying out Early Breastfeeding Initiation (IMD) activities, supporting exclusive breastfeeding and implementing joint care, not providing formula milk and not providing pacifiers or pacifiers to infants who are given ASI and seek the formation of ASI Support Groups (MOH RI, 2011: 30).

\section{OBJECTIVE}

This study aimed to analyze the relationship between postpartum maternal knowledge about Early Breastfeeding Initiation in newborns with smooth milk production at BPS Wiwik Sri Widayati, SST Tanggungan Ngraho Subdistrict, Bojonegoro District in 2018.

\section{METHODS}

This research uses analytic with cross sectional approach. The variables in this study are the knowledge of post partum mothers about Early Breastfeeding Initiation in newborns and the smooth production of breast milk.

The population in this study were all postpartum mothers at BPS Wiwik Sri Widayati, SST Tanggungan Ngraho District, Bojonegoro Regency from May to June 2018 as many as 22 people. The sample collection technique in this study was purposive sampling. With a large sample of 22 respondents.

Measuring instruments for the variable knowledge of Early Breastfeeding Initiation with questionnaires and the smoothness of ASI production variables by observation. Data 
Processing through checking Data (Editing), Grading (Scoring) and Compilation of data (Tabulating). The data analysis technique used in the study was the cross table test.

The participants were assured that their engagement was voluntary, and that anonymity, privacy, and confidentiality of the data were guaranteed. Furthermore, they were informed about the purpose and the method of the study before signing a written informed consent. The questionnaires were distributed to eligible participants at the BPS Wiwik Sri Widayati, and respondents were asked to complete and return them in the same time.

\section{RESULT}

Table 1 Distribution of knowledge of post partum mothers about Early Breastfeeding Initiation for newborns at BPS Wiwik Sri Widayati, SST Tanggungan Ngraho District Bojonegoro Regency

\begin{tabular}{llcc}
\hline No & \multicolumn{1}{c}{ Knowledge } & Frequency & $\%$ \\
\hline 1. & Less & 4 & 18,18 \\
2. & Middle & 7 & 31,82 \\
3. Good & 11 & 50,00 \\
\hline \multicolumn{2}{r}{ Total } & 22 & 100,00
\end{tabular}

Based on the above table, it can be explained that of the 22 postpartum mothers at BPS Wiwik Sri Widayati, SST Tanggungan Ngraho Subdistrict, Bojonegoro District is less than 4 people $(18.18 \%)$ less knowledgeable.

Table 2: The smooth distribution of ASI production at BPS Wiwik Sri Widayati, SST Tanggungan, Ngraho District, Bojonegoro Regency

\begin{tabular}{|c|c|c|c|}
\hline $\begin{array}{c}\text { No } \\
\text {. }\end{array}$ & $\begin{array}{l}\text { Good production of breast } \\
\text { milk }\end{array}$ & Frequency & $\%$ \\
\hline 1. & Good & 8 & 36,36 \\
\hline 2 & Not Good & 14 & 63,64 \\
\hline & Total & 22 & 100,00 \\
\hline
\end{tabular}

Based on the above table, it is explained that out of 22 postpartum mothers at BPS Wiwik Sri Widayati, SST Dependent Ngraho Subdistrict, Bojonegoro District, less than half of the smooth production of breast milk is not good by 8 people $(36.36 \%)$.

Table 3 Distribution of cross tables between knowledge of postpartum mothers about Initiation of Early Breastfeeding in newborns with good milk production

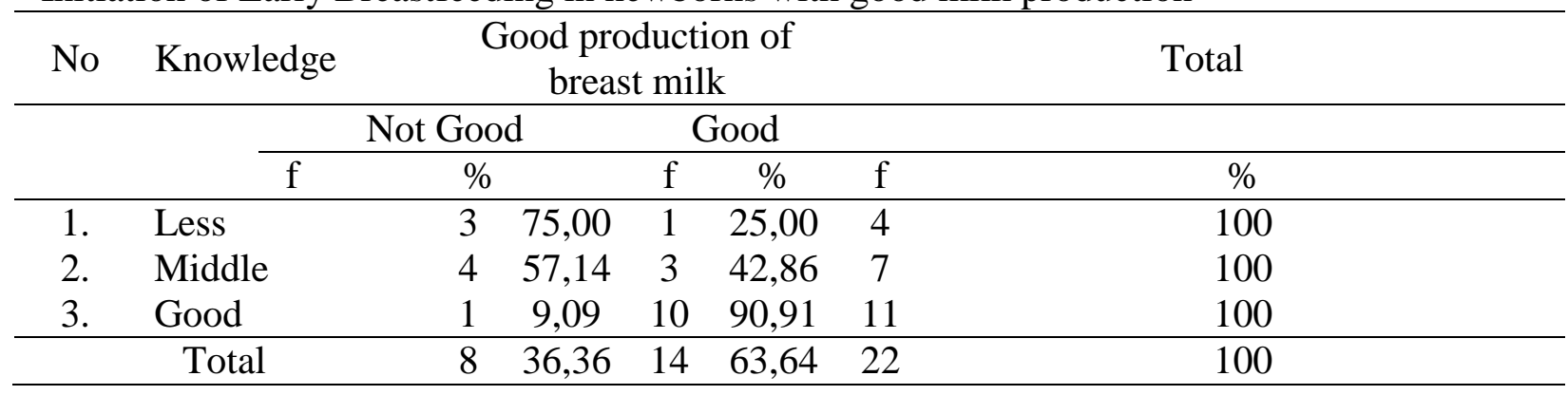




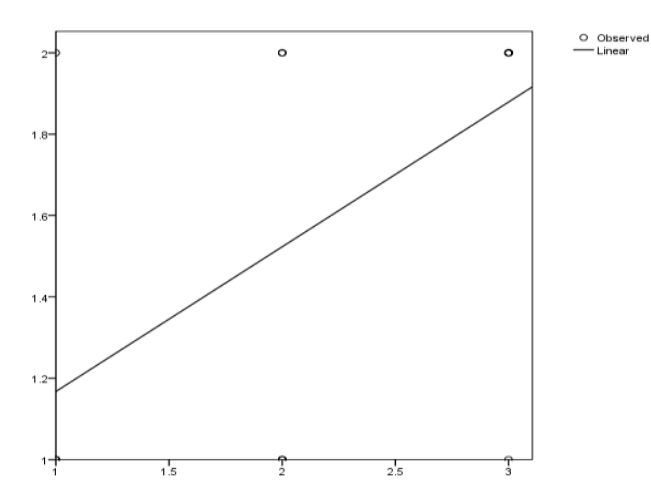

Based on the above table, it is explained that of the 4 respondents whose knowledge is less about Early Breastfeeding Initiation, the smoothness of the production of breast milk is mostly not smooth by 3 people $(75.00 \%)$ and of the 11 respondents who have good knowledge about Early Breastfeeding Initiation, the smoothness of the production of breast milk is the majority smoothly by 10 people $(90.91 \%)$.

Based on the picture above it can be proven that the two variables form a straight line or linear, that is the value of $\mathrm{x}$ (knowledge of breastfeeding initiation) changes (different) followed by changes (differences) patterned from the value of y (smooth ASI), it can be said that the more the low level of knowledge of post partum mothers about Early Breastfeeding Initiation is increasingly not smooth production of milk. So H1 is accepted that there is a relationship between postpartum maternal knowledge about Early Breastfeeding Initiation in newborns with the smooth production of breast milk in BPS Wiwik Sri Widayati, SST Tanggungan Ngraho Subdistrict, Bojonegoro District in 2018.

\section{DISCUSSION}

\section{Postpartum mother's knowledge of Early Breastfeeding Initiation in newborns}

Based on table 1 it can be explained that of the 22 post-partum mothers at BPS Wiwik Sri Widayati, SST Tanggungan Ngraho Subdistrict, Bojonegoro District is less than 4 people $(18.18 \%)$ less knowledgeable.

Knowledge is the result of knowing and this happens after people have sensed a certain object. Sensing occurs through the five human senses, namely: the sense of sight, hearing, smell, taste and touch. Most of human knowledge is obtained through the eyes and ears (Notoatmodjo, 2013: 147). Factors that influence knowledge are 1) Education is an effort to develop personality and abilities inside and outside of school (both formal and informal), lasting for life (Budiman \& Riyanto A, 2014: 4). Education, is needed to get information such as things that support health so that it can improve the quality of life. Education can affect someone including one's behavior about lifestyle, especially in motivating to participate in development attitudes, in general the higher the education, the easier it is to receive information. 2) Work is a series of tasks or activities that must be carried out or completed by someone in accordance with their respective positions or professions. (Suparyanto, 2011). Work, not a source of pleasure, but more is a way to make a living that is boring, repetitive and many challenges. While work is generally a time-consuming activity. Working for mothers will have an influence on family life. 3) Age is the length of life in the year calculated from birth. Older people are generally more responsible and more conscientious than younger ages. This happens probably because the younger are less experienced (Nursalam, 2016: 89). The more age, the level of maturity and strength of a person will be more mature in thinking and working. In terms of public trust a person who is more mature is trusted from someone who is not yet of high maturity. This will be as from the experience and maturity of the soul. 4) Environment, is all the conditions that exist around humans and their 
influence that can affect the development and behavior of people or groups and 5) Social culture, socio-cultural systems that exist in society can affect the attitude in receiving information (Wawan A \& Dewi M, 2015 : 18).

The results of the study revealed that some of the postpartum mothers at BPS Wiwik Sri Widayati, SST Tanggungan Ngraho Sub-district, Bojonegoro Regency lacked knowledge about Early Breastfeeding Initiation in newborns. Many post-partum mothers do not yet know how to do a proper Early Breastfeeding Initiation and do not know the benefits of doing an Early Breastfeeding Initiation for their babies. This can be caused by some postpartum mothers aged $<20$ years including in early adulthood so that the level of maturity and strength will be less mature in thinking and working. This causes puerperal mothers have not been able to solve complex problems, for example, an understanding of Early Breastfeeding Initiation explained by health workers, with the age of the mother does not know about IMD well because they are still selfish rather than looking for information related to Early Breastfeeding Initiation. And some postpartum mothers with basic education, where the lower the level of someone's education, the more difficult a person is to receive information, and vice versa. With education in the basic category, postpartum mothers will tend to have difficulty understanding information obtained from other people and the mass media. Where the less information that comes in, the less information obtained about health. Knowledge is very closely related to education where it is expected that postpartum mothers with basic education, the broader the knowledge, especially about Early Breastfeeding Initiation in newborns. And for postpartum mothers who have not had children, shows that in this study, puerperal mothers have less knowledge, because they do not have experience caring for children before so mothers have not been able to prepare everything needed to provide the best for their children. As well as more than a portion of respondents working as entrepreneurs so that most of their time is spent on work and cannot attend or attend counseling conducted by health workers, then with the busyness of the respondents they do automatically time to access information sources related to Initiation issues Early breastfeeding through mass media, electronic or via the internet cannot be respected so that respondents' knowledge about Early Breastfeeding Initiation is in the category of lacking

\section{Good breast milk production in postpartum mothers}

Based on table 2, it is explained that from 22 post-partum mothers at BPS Wiwik Sri Widayati, SST Dependent Ngraho Subdistrict, Bojonegoro District, less than half of the smooth production of ASI was not smooth by 8 people $(36.36 \%)$.

In normal mothers can produce milk around 550-1000 ml every day, the amount of milk can be influenced by several factors as follows: 1) Food, milk production is strongly influenced by the food the mother eats, if the mother's food is regular and contains enough Necessary nutrients will affect milk production, because the glands of breast milk makers can not work perfectly without adequate food. To form a good milk production, mother's food must meet the number of calories, protein, fat and vitamins and minerals that are sufficient besides the mother is recommended to drink more or less 8-12 glasses / day, 2) Peace of mind and mind, milk production is strongly influenced by psychiatric factors, mothers who are always in a state of distress, sadness, lack of confidence and various forms of emotional tension will reduce the volume of breast milk and will not even produce milk. To produce good milk, it must be calm. 3) Use of contraception, for mothers who breastfeed their babies use of contraception should be considered because improper use of contraception can affect the production of breast milk. 4) Breast care, by stimulating the breasts will affect hypopise to release more progesterone and estrogen hormones and oxytocin. 5) Anatomical breasts, if the 
number of lobes in the breast is reduced, the lobules are reduced. Thus the production of breast milk is also reduced because acini cells that suck food substances from blood vessels will decrease. 6) Physiology, the formation of breast milk is influenced by hormones, especially prolactin, which is a lactogenic hormone that determines the procurement and maintenance of milk secretion. 7) Resting factor, if lack of rest will experience weakness in carrying out its functions thus the formation and expenditure of breast milk is reduced. 8) Drug factors, it is estimated that drugs containing hormones affect the hormones prolactin and oxytocin which function in the formation and release of breast milk. If these hormones are disrupted by itself will affect the formation and expenditure of milk (Kristiyansari W, 2009: 14).

The results of research in postpartum mothers at BPS Wiwik Sri Widayati, SST Tanggungan Ngraho District, Bojonegoro Regency is less than part of the smooth production of breast milk. This could be due to more than postpartum mothers not having children before or the first time. So many postpartum mothers who feel scared and insecure because they feel very little milk is released after giving birth to a baby. Mothers who have just given birth have a small amount of colostrum, does not mean that the amount of milk released is not much. too much negative thinking and worry too much will affect the hormone oxytocin which can be inhibited. Feelings that are less calm can make the performance of oxytocin goes bad, feelings that are not calm and less free from fear, worry, anger, upset, and sadness will make the mother not relax while breastfeeding her baby. Uncomfortable feelings when breastfeeding can make milk production decrease. Vice versa, the more children born will affect the productivity of breast milk. Mothers who have given birth before, milk production is much higher than mothers who have never given birth. The number of deliveries a mother has experienced provides experience in breastfeeding babies. The more parity the mother will be more experienced in giving milk and know how to increase milk production so that there is no problem for mothers in giving

\section{The relationship of postpartum maternal knowledge about Early Breastfeeding Initiation in newborns with the smooth production of breast milk}

Based on table 3, it is explained that of the 4 respondents whose knowledge is less about Early Breastfeeding Initiation, the smoothness of the production of breast milk is mostly not smooth by 3 people $(75.00 \%)$ and from 11 respondents who have good knowledge about Early Breastfeeding Initiation, the smoothness of the production of breast milk is smoothly majority. by 10 people $(90.91 \%)$. Based on the Spearman Rho correlation test results obtained $\mathrm{p}$ value $=0.005<\alpha(0.05)$, then $\mathrm{H} 1$ is accepted there is a relationship of postpartum maternal knowledge about Early Breastfeeding Initiation in newborns with smooth milk production at BPS Wiwik Sri Widayati, SST Tanggungan Kecamatan Ngraho Bojonegoro Regency in 2018. With a correlation of 0.577 (enough) and a positive correlation direction.

Early Breastfeeding Initiation or the beginning of early breastfeeding is the baby starts breastfeeding himself after birth. Contact between the baby and her mother's skin is left for at least one hour immediately after birth, then the baby will look for the mother's breast by itself. The way the baby initiates breastfeeding is called the brest crawl or crawl looking for breasts (Sondakh JS, 2013: 170). Benefits of Early Breastfeeding Initiation include 1) Benefits of IMD for babies: When the baby is placed on the mother's chest, then he will feel warm, reducing the risk of hypothermia / lack of body temperature in the baby's body. Skin contact between mother and baby psychologically can also bring them closer together, IMD helps train the baby in motor motor coordination, sucking, swallowing and breathing, automatically training the baby to suckle. IMD allows exclusively breastfed babies for longer, because 
breast milk production is stimulated as soon as possible. The very important thing is the chance of the baby to get the first milk out which is called colustrum. This collagen contains important substances and antibodies (immunity) which are very useful to maintain the body's resistance to infection and contain anti-allergic substances. This column will protect the baby's intestines and mature the intestines of newborns. 2) Benefits of IMD for mothers: When breastfeeding, the mother releases the hormone oxytocin in her body. This hormone is useful for uterine contractions, so the uterus can contract and re-shape as before, helping to remove the remnants of childbirth in the uterus, and reduce postpartum bleeding. The prolactin hormone is also produced to increase and expedite milk production after childbirth and during breastfeeding. The more often you breastfeed, the better the milk. Other hormones are also produced so that the mother can become more relaxed after giving birth. IMD also fosters a mother's affection for her baby through the touch, eye contact and sound issued by her baby. ASI is free. And breastfeeding in full provides certain contraceptive effects (Armadhi H, 2015: 2).

From the results of the study showed that there was a relationship between postpartum maternal knowledge about Early Breastfeeding Initiation in newborns with the smooth production of breast milk in BPS Wiwik Sri Widayati, SST Tanggungan Ngraho District, Bojonegoro Regency. Mother's knowledge about IMD is one important factor in the successful implementation of IMD. Many mothers do not know the Early Breastfeeding Initiation, how to do Early Breastfeeding Initiation for their babies and do not know the benefits of Early Breastfeeding Initiation for mothers. Often mothers have incorrect understanding, for example they do not need to feed the baby because breast milk has not come out or because milk that comes out first and is yellow is dirt and stale. Other things that make breastfeeding delayed are for example the mother feels thirsty and needs to rest first because she is tired, still feeling sick, or thinks the baby needs to be bathed first. Where these reasons should not lead to postponement of the implementation of the Early Breastfeeding Initiation that is important for the baby and mother, while the Early Breastfeeding Initiation (IMD) is a way of giving the newborn opportunity to feed the mother in the first hour of life. Touching the baby through suction reflexes that arise from 30-40 minutes after birth will cause sensory stimulation in the brain of the mother to produce the hormone prolactin which can facilitate the production of breast milk and can provide a sense of security to the baby.

\section{CONCLUSION}

Less than most postpartum mothers have less knowledge about Early Breastfeeding Initiation in newborns and Less than most postpartum mothers smooth breast milk production in the non-current category.

There is a relationship between postpartum mothers' knowledge about Early Breastfeeding Initiation in newborns and the smooth production of breast milk. With a large enough correlation and positive correlation direction. This means that the better the knowledge of post partum mothers about Early Breastfeeding Initiation, the smoother the production of breast milk will be. 


\section{REFERENCES}

Armadhi H. 2015. Buku Pedoman Menyusui. Surabaya.

Baskoro A. 2008. ASI Panduan Praktis Ibu Menyusui. Banyu Media. Yogyakarta.

Depkes RI. 2010. Paket Modul Kegiatan Inisiasi Menyusu Dini (IMD) dan ASI Eksklusif 6 Bulan. Jakarta.

Hidajaturrokhmah, N. Y., \& Saputro, H. 2016. Pertumbuhan Berat Badan Bayi Usia 6 Bulan Ditinjau dari Jenis Nutrisi. STRADA Jurnal Ilmiah Kesehatan, 5(1), 38-45.

Irsal FS. 2017. a to z ASI dan menyusui. Pustaka Bunda. Jakarta.

Kristiyansari W. 2009. ASI, Menyusui \& Sadari. Nuha Medika. Salemba Medika

Rosita S. 2008. ASI Untuk Kecerdasan Bayi. Penerbit Ayyana. Yogyakarta.

Sondakh JS. 2013. Asuhan Kebidanan Persalinan \& Bayi Baru Lahir. Erlangga. Jakarta.

Wawan A \& Dewi M. 2015. Teori \& Pengukuran Pengetahuan, Sikap dan Perilaku Manusia. Nuha Medika. Yogyakarta 